\title{
Tinjauan Yuridis Terhadap Keputusan Tata Usaha Negara Yang Merupakan Perbuatan Hukum Perdata
}

\author{
Mutia Jawaz Muslim \\ Pusat Advokasi Hukum dan HAM, Jakarta
}

E-mail: mutiajawazmuslim@gmail.com

\begin{abstract}
This research departs from the problem of obscurity of the concept of a State Administration Decree which is a civillaw set out in article 2 letter a of Law Number 5 of 1986 concerning State Administrative Court as an exception to absolute competence which in practice creates confusion in interpretation for law enforcement and the community thus often brings up jurisdictional intersections adjudicating between the State Administrative Court and the General Court. Theoretically, the concept of a State Administrative Decree which is a civil law act is interpreted as an action taken by the government based on public law to deliver the government in conducting civil relations so that it is considered merged into civil action. However, this concept is not easily understood in practice so that an integrated justice system, simple, fast, and low cost is still far from the expectations of justice seekers.
\end{abstract}

\section{Keywords: State Administrative Decisions which are Acts of Civil Law, Absolute Competence, State Administrative Courts}

Penelitian ini berangkat dari permasalahan ketidakjelasan dari konsep Keputusan Tata Usaha Negara yang merupakan perbuatan hukum perdata yang diatur dalam pasal 2 huruf a Undang-Undang Nomor 5 Tahun 1986 Tentang Peradilan Tata Usaha Negara sebagai pengecualian kompetensi absolut dimana dalam praktiknya menimbulkan kebingungan dalam penafsiran bagi penegak hukum dan masyarakat sehingga sering memunculkan persinggungan yuridiksi mengadili antara Peradilan Tata Usaha Negara dan Peradilan Umum. Secara teoritis Konsep dari Keputusan Tata Usaha Negara yang merupakan perbuatan hukum perdata dimaknai sebagai tindakan pemerintah yang dilakukan berdasarkan hukum publik untuk mengantarkan pemerintah dalam melakukan hubungan perdata sehingga dianggap melebur ke dalam tindakan perdata. Namun konsep ini tidak dipahami secara mudah dalam prakteknya sehingga sistem peradilan yang terintegrasi, sederhana, cepat, dan biaya ringan masih jauh dari harapan para pencari keadilan.

.Kata kunci : Keputusan Tata Usaha Negara yang merupakan Perbuatan Hukum Perdata, Kompetensi Absolut, Peradilan Tata Usaha Negara

\section{PENDAHULUAN}

Gugatan yang timbul sebagai akibat dari lahirnya Keputusan Tata Usaha Negara yang merupakan perbuatan hukum perdata menurut Pasal 2 huruf a Undang-Undang Nomor 5 Tahun 1986 Juncto Undang-Undang Nomor 9 Tahun 2004 Juncto Undang-Undang Nomor 51 Tahun 2009 Tentang perubahan kedua atas Undang-Undang Nomor 5 Tahun 1986 Tentang Peradilan Tata Usaha Negara sudah seharusnya menjadi Kompetensi Absolut Pengadilan Tata Usaha Negara (PTUN), hal ini demi menciptakan suatu proses peradilan yang terintegrasi, sederhana, cepat, dan biaya ringan. Kondisi ini disebabkan karena masih adanya sengketa administrasi yang diselesaikan di Pengadilan Negeri sehingga dalam praktik dilapangan sering terjadi persinggungan yuridiksi mengadili baik itu di Pengadilan Tata Usaha Negara maupun Pengadilan Negeri. 
Kehadiran Peradilan Tata Usaha Negara sebagai perwujudan dari sistem kenegaraan di Indonesia yang menganut prinsip negara hukum (rechtstaat), sebagaimana yang dikehendaki oleh UUD 1945. Tujuan dari pembentukan PTUN itu sendiri untuk memberikan perlindungan kepada warga negara yang hak-hak nya dirugikan oleh tindakan pemerintah yang bertentangan dengan peraturan perundang-undangan yang berlaku serta asas-asas umum pemerintahan yang baik. Fungsi PTUN pada dasarnya adalah sebagai sarana untuk menyelesaikan konflik yang timbul antara pemerintah (badan/pejabat TUN) dengan rakyat (orang atau badan hukum perdata) sebagai akibat dikeluarkannya atau tidak dikeluarkannya Keputusan Tata Usaha Negara (KTUN). ${ }^{[1]}$

PTUN dalam menjalankan fungsi dan tujuannya diberikan kewenangan absolut sebagaimana yang terdapat dalam Pasal 1 angka 3 Undang-Undang Nomor 5 Tahun 1986 Tentang Peradilan Tata Usaha Negara dimana yang menjadi kompetensi absolut PTUN adalah KTUN yang berupa suatu penetapan tertulis yang dikeluarkan oleh Badan atau Pejabat Tata Usaha Negara yang berisi tindakan hukum Tata Usaha Negara yang berdasarkan peraturan perundang-undangan yang berlaku, yang bersifat konkret, individual, dan final, yang menimbulkan akibat hukum bagi seseorang atau badan hukum perdata. ${ }^{[2]}$ Berdasarkan rumusan pasal ini, dapat dipahami bahwa suatu KTUN adalah produk yang diterbitkan oleh pejabat TUN (atau jabatan TUN) berdasarkan wewenang yang ada padanya (attribute) atau diberikan padanya dalam bidang urusan pemerintah (delegate). ${ }^{[3]}$

Pengertian Keputusan Tata Usaha Negara yang tidak termasuk dalam ruanglingkup kompetensi Peradilan Tata Usaha Negara di Indonesia, dirumuskan dalam ketentuan Pasal 2 Undang-Undang Nomor 5 Tahun 1986 Jo Undang-Undang Nomor 9 Tahun 2004 Jo Undang-Undang Nomor 51 Tahun 2009 Tentang Peradilan Tata Usaha Negara. Berdasarkan pasal 2 huruf a tersebut yang bukan termasuk dalam pengertian KTUN adalah "Keputusan Tata Usaha Negara yang merupakan perbuatan hukum perdata".

Pengecualian Kompetensi Absolut Peradilan Tata Usaha Negara berdasarkan Pasal 2 huruf a Undang - Undang Nomor 5 Tahun 1986 Jo Undang-Undang Nomor 9 Tahun 2004 Jo UndangUndang Nomor 51 Tahun 2009 Tentang Peradilan Tata Usaha Negara ${ }^{[4]}$ tidak menyebutkan secara rinci tentang apa dan bagaimana KTUN yang merupakan perbuatan hukum perdata. Penjelasan pasal 2 butir a menyebutkan : Keputusan Tata Usaha Negara yang merupakan perbuatan hukum perdata, umpamanya keputusan yang dilakukan antara instansi pemerintah dengan perseorangan yang didasarkan pada ketentuan hukum perdata.

Ketentuan KTUN yang merupakan perbuatan hukum perdata diatas dilihat dari segi peristilahan, menimbulkan kerancuan atau kontradiksi istilah (contradiction in termino), karena istilah Keputusan Tata Usaha Negara merupakan istilah khas sebagai keputusan yang dikeluarkan berdasarkan hukum publik. Oleh karena itu KTUN yang merupakan perbuatan hukum perdata merupakan hal yang janggal dan membingungkan apabila dikatakan tidak termasuk Keputusan Tata Usaha Negara. Sesungguhnya tidaklah tepat adanya Keputusan Tata Usaha Negara yang merupakan perbuatan hukum perdata. Oleh karenanya istilah KTUN yang merupakan perbuatan hukum perdata patut dipertimbangkan kembali karena istilah itu dalam praktik Peradilan Tata

\footnotetext{
1 Muhammad Nasir, Hukum Acara Peradilan Tata Usaha Negara, (Jakarta :Djambatan, 2003), hlm. 3.

2 Indonesia, Undang-Undang Pengadilan Tata Usaha Negara, UU No. 5 Tahun 1986, LN No. 77 Tahun 1986. TLN No. 3344.

3 Paulus Effendi Lotulung, Hukum Tata Usaha Negara dan Kekuasaan, (Jakarta : Salemba Humanika, 2013), hlm. 27.

4 Indonesia, Undang - Undang Peradilan Tata Usaha Negara. UU No. 5 Tahun 1986. LN Nomor 77 Tahun 1986, TLN No. 3344, Ps. 2.
} 
Usaha Negara diluar sengketa tata usaha negara. ${ }^{[5]}$ Sebagai konsekuensi yang negatif dari rumusan yang tidak jelas mengenai hakekat KTUN yang merupakan perbuatan hukum perdata, dalam praktik melahirkan tumpang tindih kompetensi absolut Peradilan Tata Usaha Negara dengan Peradilan lainnya, khususnya Peradilan Umum.

Keikutsertaan badan atau pejabat TUN di dalam perbuatan hukum keperdataan, bukan tidak mungkin berbagai ketentuan hukum publik (hukum tata usaha Negara) akan menyusup dan mempengaruhi peraturan perundang-undangan hukum perdata. Seperti ketentuan peraturan perundang-undangan yang secara khusus mengatur tata cara atau prosedur tertentu yang harus ditempuh berkenaan dengan upaya perbuatan hukum keperdataan yang dilakukan oleh badan atau pejabat TUN. Misalnya, badan atau pejabat TUN tidaklah dengan begitu saja melakukan pembelanjaan (pengadaan) barang dan jasa bagi kebutuhan departemen/lembaga tanpa melalui tata cara dan prosedur yang telah ditetapkan apalagi pembelanjaan itu dilakukan dalam rangka pelaksanaan Anggaran Pendapatan dan Belanja Negara. ${ }^{[6]}$ Setiap perjanjian perdata yang dilakukan oleh pemerintah tidak terlepas dari ketentuan hukum publik yang mempengaruhi berlakunya ketentuan hukum perdata.

Kemudian muncul suatu pertanyaan mengapa hakim perdata setelah diundangkannya UU No. 2 Tahun 1986 tentang Peradilan Umum tetapi masih berwenang mengadili gugatan perdata terhadap pemerintah mengenai tindakan pemerintah di dalam melaksanakan tugas kewajibannya berdasarkan wewenang-wewenang pemerintahan yang diberikan oleh hukum publik. ${ }^{[7]}$ Bukankah sengketa yang timbul dari tindakan - tindakan pemerintah demikian itu bukan merupakan sengketa hukum perdata, tetapi merupakan sengketa TUN dimana hakim perdata hanya ditugaskan menyelesaikan perkara yang murni perdata saja. Janggal kalau hakim perdata menguji apakah perbuatan penguasa/pemerintah yang digugat dalam gugatan yang "diberi baju gugatan perdata" tersebut dinilai oleh hakim perdata bersifat melawan hukum. ${ }^{[8]}$

Disisi lain, pasca disahkannya Undang - Undang Nomor 30 tahun 2014 tentang Administrasi Pemerintahan telah terjadi perluasan terhadap makna Keputusan Tata Usaha Negara (KTUN) sehingga juga berakibat pada perluasan yurisdiksi mengadili PTUN. Tindakan materiil atau faktual pemerintah yang sebelumnya menjadi kewenangan Pengadilan Umum untuk mengadilinya berupa gugatan ganti rugi atas perbuatan melawan hukum namun sekarang menjadi kompetensi absolutnya PTUN.

Berdasarkan uraian permasalahan di atas, maka penelitian yang akan dilaksanakan adalah: Pertama Bagaimanakah Konsep Keputusan Tata Usaha Negara yang merupakan Perbuatan Hukum Perdata sebagaimana yang diatur dalam Pasal 2 huruf a Undang-Undang Nomor 5 Tahun 1986 tentang Peradilan Tata Usaha Negara ? Dan kedua, Bagaimanakah problematika KTUN yang merupakan perbuatan hukum perdata di Peradilan Tata Usaha Negara?

Penelitian yang dilaksanakan berdasarkan metodologi penelitian hukum normatif yang pada

5 Kamarullah, "Keputusan Tata Usaha Negara yang merupakan Perbuatan Hukum Perdata berdasarkan Kentuan pasal 2 butir a Undang - Undang Nomor 5 Tahun 1986 Juncto Undang-Undnag Nomor 9 Tahun 2004 tentang Perubahan atas Undangundang Nomor 5 Tahun 1986 Tentang Peradilan Tata Usaha Negara", Disertasi Program Pascasarjana UNAIR, Surabaya, 2008, hlm. 5.

6 Philipus M.Hadjon, Penggunaan Instrumen Hukum Perdata Oleh Pemerintah, Pelatihan Hukum bagi Dosen dan Praktisi, Fakultas Hukum UNAIR, Surabaya, tanggal 6-7 September 2006, dalam Disertasi Kamarullah, hlm. 8.

7 Indroharto, Usaha Memahami Undang - Undang Tentang Peradilan Tata Usaha Negara, Buku I, (Jakarta : Pustaka Sinar Harapan, 2002), hal.39.

8 Ibid. 
dasarnya terdiri atas aspek pembentukan hukum dan penerapan hukum. ${ }^{[9]}$ Menurut Soerjono Soekanto, penelitian hukum normatif adalah penelitian kepustakaan, ${ }^{[10]}$ yang dalam penelitian ini dilaksanakan terhadap Restrukturisasi Kompetensi Absolut PTUN terhadap Keputusan Tata Usaha Negara yang merupakan perbuatan hukum perdata. Penelitian dilaksanakan dengan mengacu pada norma hukum yang terdapat di dalam peraturan perundang-undangan yang didukung dengan data putusan MA yang sesuai dengan topik penelitian. Metode penelitian yang digunakan dalam penelitian ini adalah studi kepustakaan sebagai data sekunder, yang bertujuan menunjukkan jalan pemecahan permasalahan penelitian, ${ }^{[11]}$ yang meliputibahan hukum primer, yaituberbagaiperaturan perundang-undangan terkait dengan kompetensi mengadili PTUN, Keputusan Tata Usaha Negara, serta Putusan MA mengenai KTUN yang merupakan perbuatan hukum perdata. Di samping itu, dibutuhkan pula bahan hukum sekunder untuk memberi penjelasan mengenai data hukum primer, yang meliputi buku, artikel, tulisan karya ilmiah dalam jurnal ilmiah. Selain bahan hukum primer dan sekunder, digunakan pula bahan hukum tersier berupa kamus hukum yang berkaitan dengan topik penelitian di atas. Setelah data sekunder diperoleh, kemudian dilaksanakan pengolahan dan penganalisisan data secara kualitatif untuk menggambarkan fakta yuridis dalam penilaian terhadap KTUN yang merupakan perbuatan hukum perdata. Tipe penelitian yang diterapkan oleh penulis adalah preskriptif yang pada akhirnya akan memberikan gambaran yang komprehensif serta saran atas kompetensi absolut PTUN terhadap KTUN yang merupakan perbuatan hukum perdata.

\section{PEMBAHASAN}

Aspek teoritis terhadap keputusan tata usaha negara yang merupakan perbuatan hukum perdata dari permasalah dalam tulisan ini dapat dilihat dari beberapa hal antara lain adalah :

\section{Fungsi Kontrol Yuridis PTUN}

Dalam konsep hukum administrasi, tindakan pemerintah merupakan tindakan atau perbuatan yang dilakukan oleh administrasi negara dalam melaksanakan urusan pemerintahan. Tindakan ini meliputi tindakan berdasarkan hukum privat dan tindakan berdasarkan hukum publik. ${ }^{[12]}$ Menurut Philipus M Hadjon dalam konsep hukum kemasyarakatan dan pada sisi lain memungkinkan masyarakat berpartisipasi dalam pengendalian (pemerintah) tersebut. ${ }^{[13]}$ Salah satu kendali yang bisa dilakukan msyarakat terhadap pemerintah adalah melalui kendali Peradilan Tata Usaha Negara.

Teori kontrol yuridis bertitik tolak dari suatu pemikiran yang mengatakan, bahwa pihak pemerintah sebagai pihak penguasa mempunyai posisi yang kuat, memiliki kekuasaan (power), dibandingkan dengan masyarakat atau anggota masyarakat yang dilayaninya. ${ }^{[14]}$ Kekuasaan tersebut apabila tidak diawasi pelaksanaannya, ada kecendrungan untuk disalah gunakan. Oleh karena itu, pihak masyarakat atau anggota masyarakat, sebagai pihak yang lemah perlu dilindungi, terutama dari segi hukum. Bagir Manan mengatakan : “... Sejarah telah memberikan contoh dan bukti yang

\footnotetext{
9 Johny Ibrahim, Teori dan Metodologi Penelitian Hukum Normatif(Malang: Bayumedia, 2006), hlm. 299-322. Sebagaimana dikutip dalam Dian Puji N. Simatupang, Paradoks Rasionalitas, hlm. 65.

10 Soerjono Soekanto dan Sri Mamudji, Penelitian Hukum Normatif Suatu Tinjauan Singkat, ed. 1, cet. 10 (Jakarta: RajaGrafindo Persada, 2007), hlm. 23.

${ }^{11}$ Bambang Sunggono, Metodologi Penelitian Hukum (Jakarta: RajaGrafindo Persada, 2007), hlm. 112.

12 Philipus M Hadjon, Pengertian-Pengertian Dasar Tentang Tindak Pemerintah (bestuurshandeling), Fak Hukum UNAIR, Surabaya, 1987, hlm. 1-3.

${ }^{13}$ Philipus M Hadjon, Beberapa Catatan Tentang Hukum Administrasi, Makalah Fakultas Hukum UNAIR, Surabaya, 1993 hlm. 3

14 Ibid. hlm. 21
} 

hilangnya kebebasan serta kemerdekaan warganegara atau penduduk negara yang bersangkutan..." [15]

PTUN atau disebut juga pengadilan administrasi bertugas melakukan kontrol terhadap pemerintah dari segi hukum (yuridis). Mekanisme kontrol tersebut berjalan melalui suatu proses persidangan, apabila ada gugatan dari seorang individu atau badan hukum perdata kepada pihak pemerintah, manakala ada keputusan Pemerintah yang dirasakan merugikan kepentingan mereka. PTUN dengan segala kewenangan-kewenangan yang ada padanya, melalui instrument-instrumen hukum yang dimilikinya, melakukan tindakan-tindakan dan putusan-putusan hukum tentang sah tidaknya keputusan-keputusan pemerintah tersebut dari segi hukum. Apabila perlu PTUN dapat memerintahkan pihak pemerintah untuk mengubah keputusannya yang cacat tersebut, sesuai dengan hukum.

\section{Teori Melebur}

Instrumen hukum keperdataan yang sering digunakan oleh pemerintah adalah berupa perjanjian perdata. Setiap perjanjian yang dilakukan pemerintah tersebut selalu didahului oleh adanya suatu Keputusan Tata Usaha Negara (KTUN) yang lahir dari hukum publik yang dikeluarkan untuk melakukan suatu tindakan hukum perdata. Setelah dibuatnya keputusan TUN tersebut, maka barulah dilakukan perjanjian perdata (tindakan hukum perdata) yang dimaksud. ${ }^{[16]}$

Persoalannya kemudian adalah keputusan TUN untuk melakukan suatu tindakan hukum perdata itu, apa atau bagaimana kualifikasinya? Apakah ia merupakan keputusan TUN ataukah ia merupakan tindakan pemerintah dalam bidang hukum perdata? kalau itu merupakan suatu KTUN maka apabila terjadi suatu sengketa dikemudian hari mengenai pelaksanaan perjanjian perdata yang telah terjadi, maka hal itu masuk dalam kompetensi absolut PTUN. Sebaliknya apabila keputusan itu dianggap melebur ke dalam tindakan hukum perdata, sehingga apabila terjadi sengketa dikemudian hari maka penyelesaiannya menjadi kompetensi absolut hakim perdata (Pengadilan Negeri). ${ }^{[17]}$ UU No. 5 tahun 1986 dengan ketentuan pasal 2 huruf a menjurus dan cenderung untuk menganggap keputusan TUN semacam itu melebur dalam tindakan hukum perdata yang menjadi tujuan akhirnya.

Sebagai contoh dapat di ambil Pasal 61 Undang - undang Nomor 5 Tahun $1974^{[18]}$ yang merujuk Badan atau Pejabat TUN tertentu untuk bertindak atas nama badan-badan (hukum) publiknya yang berkedudukan sebagai badan hukum perdata. Dalam pasal ini ditentukan, bahwa keputusan kepala daerah untuk mengadakan utang piutang atau menanggung pinjaman bagi kepentingan dan atas beban daerah yang harus dilakukan dengan persetujuan DPRD itu baru berlaku sesudah ada pengesahan dari Mendagri.

Pengesahan Mendagri tersebut merupakan pelaksanaan dari segi pengawasan administratif

${ }_{15}$ Bagir Manan, "Dewan Konstitusi di Perancis", makalah tanpa menyebutkan tempat, waktu dan acara dimana disajikan, hlm 1. Selanjutnya pada bagian lain dari tulisan itu dikatakan perlu adanya kontrol terhadap pemerintah/penguasa, baik control yudisial (judicial review), maupun control politik (political review). Khusus pengawasan yuridis, diserahkan kepada salah satu badan peradilan atau semua badan peradilan atau semua badan peradilan (judicial review). Cara lain untuk melakukan pengawasan adalah melalui lembaga Ombudsman, yaitu suatu lembaga yang dikembangkan di Negara-negara Scandinavia, dan sekang berkembang di NegaraNegara lain, seperti : inggris dan New Zealand, dalam lintong siahaan, Prospek PTUN, hlm. 21

${ }^{16}$ Indroharto, Usaha Memahami Undang-Undang, hlm. 117.

17 Ibid.

${ }^{18}$ Indonesia, Undang-Undang Pokok-Pokok Pemerintahan Di Daerah, UU Nomor 5 Tahun 1974. 
yang preventif sifatnya yang dikeluarkan berdasarkan ketentuan-ketentuan hukum publik yang mendahului berlakunya perbuatan-perbuatan hukum perdata yang dalam hal ini berupa : mengadakan utang piutang atau menanggung pinjaman bagi kepentingan dan atas beban Daerah.

Dengan demikian suatu keputusan untuk mengadakan suatu perjanjian pinjam meminjam itu berbeda dengan Keputusan Menteri yang berisi penolakan atau menyetujui perbuatan pinjam meminjam yang akan dilakukan daerah yang bersangkutan, demikian pula keputusan untuk mengadakan perjanjian jual beli atau sewa menyewa dapat dibedakan dari perbuatan mengadakan perjanjian jual beli atau sewa menyewa itu sendiri.

Persoalannya dalam hal ini lalu apakah keputusan pengesahan yang dilakukan Mendagri itu merupakan penetapan tertulis menurut pengertian Pasal 1 ayat 3 undang - undang PTUN ? sebab pasal 2 huruf a tersebut hanya mengatakan tentang Keputusan TUN yang merupakan perbuatan hukum perdata. Apabila kedua macam keputusan itu harus dipisah dan dinilai sendiri-sendiri, artinya keputusan pengesahan Mendagri dan keputusan Kepala Daerah untuk mengadakan suatu perjanjian jual beli atau sewa menyewa dianggap sebagai suatu penetapan tertulis sedang perjanjian perdatanya yang terjadi tetap merupakan suatu perbuatan hukum perdata, maka akan terjadi keadaan yang membingungkan, baik bagi pencari keadilan maupun bagi para Hakim TUN sendiri. Apabila kedua macam keputusan yang bersumber kepada ketentuan hukum publik itu harus dianggap sebagai Keputusan TUN dan hanya dapat diadili oleh Hakim TUN sedang perbuatan hukum perdatanya yang berupa perjanjian perdata menjadi kompetensi Hakim Perdata akan besar terjadinya pertentangan dalam kedua macam bentuk Putusan Hakim tersebut. Pada hal baik Keputusan Kepala Daerah yang telah memperoleh persetujuan DPRD dan Keputusan Mendagri yang berisi menyetujui atau menolak itu, semuanya ditujukan untuk menentukan bisa tidaknya dilakukan perbuatan hukum perdata yang berupa : mengadakan perjanjian utang piutang untuk kepentingan Daerah yang bersangkutan. Oleh karena itu pemecahannya lalu : kedua macam Keputusan TUN tersebut dianggap melebur ke dalam perbuatan hukum perdatanya, karena perbuatan hukum terakhir inilah yang memang dimaksudkan agar bisa dilakukan oleh Badan atau Pejabat TUN yang bersangkutan. Ukuran demikian pula yang tampak diikuti dalam Yurisprudensi tetap dari Afdeling Rechtspraak R.v.State. ${ }^{[19]}$

Sejalan dengan teori tersebut menurut Ten Berge \& Tak, yang berusaha merinci keputusankeputusan TUN mana saja yang dapat dianggap sebagai rechtshandeling naar burgerlijkrecht (tindakan hukum menurut hukum perdata) adalah :[20]

a. Keputusan TUN yang jangkauannya akan melahirkan atau justru menolak terjadinya suatu perbuatan hukum perdata, umpama keputusan penolakan untuk menjual suatu rumah dinas kepada seorang pegawai; penolakan Perumtel untuk memberikan sambungan telepon.

b. Keputusan TUN yang akan melebur dalam suatu perbuatan hukum perdata, contoh diatas juga berlaku disini. Contoh lain : Keputusan TUN yang berisi akan menyewa suatu gedung untuk kantor;

c. Keputusan TUN yang menyebabkan dipenuhi atau justru tidak dipenuhinya suatu syarat yang perlu harus ada agar suatu perbuatan hukum perdata dapat bekerja dengan sah. Contohnya : tempo hari suatu instansi yang akan memborongkan pekerjaaan di atas platfond Rp. 500

\footnotetext{
${ }^{19}$ Indroharto, Usaha Memahami Undang-Undang, hlm. 117.

${ }^{20}$ Ibid., hlm. 18.
} 
juta harus memperoleh persetujuan dari Setneg terlebih dahulu; Keputusan Setneg ini dapat merupakan contoh Keputusan TUN yang dimaksud disini.

d. Keputusan TUNyang merupakan pelaksanaan dari suatu perbuatan hukum perdata, umpamanya : Keputusan yang memberikan Izin Menghuni suatu rumah yang dibangun atas dasar perjanjian antara Walikota dengan suatu Real Estate.

\section{A. Konsep Keputusan Tata Usaha Negara yang Merupakan Perbuatan Hukum Perdata}

Istilah Keputusan Tata Usaha Negara yang merupakan perbuatan hukum perdata muncul dalam Pasal 2 butir a Undang-Undang Nomor 5 Tahun 1986 tentang Peradilan Tata Usaha Negara sebagai pembatasan terhadap kompetensi absolut PTUN. Dalam pasal ini tidak di sebutkan secara rinci tentang apa dan bagaimana Keputusan Tata Usaha Negara yang merupakan perbuatan hukum perdata. Penjelasan pasal 2 butir a menyebutkan, Keputusan Tata Usaha Negara yang merupakan perbuatan hukum perdata, misalnya keputusan yang menyangkut masalah jual beli yang dilakukan antara instansi pemerintah dan perseorangan yang didasarkan pada ketentuan hukum perdata. ${ }^{[21]}$

Penamaan "Keputusan Tata Usaha Negara yang merupakan perbuatan hukum perdata" diatas dilihat dari segi peristilahan maka menimbulkan kerancuan atau terjadi "kontradiksi istilah" (contradiction in termino). Apabila dibandingkan dengan definisi Keputusan Tata Usaha Negara menurut Undang-Undang Nomor 5 Tahun 1986 Tentang Peradilan Tata Usaha Negara dimana KTUN merupakan penetapan tertulis yang dikeluarkan oleh Badan atau Pejabat Tata Usaha Negara berdasarkan hukum tata usaha negara yang bersifat konkrit, individual dan final yang menimbulkan akibat hukum bagi seseorang atau badan hukum perdata, maka dari penjelasan ini KTUN adalah sebagai produk hukum publik sehingga sangat aneh dan kontradiksi apabila kemudian disisipkan dengan kata "perbuatan hukum perdata". Oleh karena itu Keputusan Tata Usaha Negara yang merupakan perbuatan hukum perdata merupakan hal yang janggal dan membingungkan apabila dikatakan tidak termasuk Keputusan Tata Usaha Negara.

Apabila dilihat kembali dalam tataran teorinya, tindakan hukum pemerintah terbagi kedalam dua kelompok yaitu tindakan pemerintah berdasarkan hukum publik serta tindakan pemerintah berdasarkan hukum privat. Selain tentunya bertindak dalam ranah publik, pemerintah dalam menjalankan fungsi-fungsi pemerintahan juga tidak jarang menggunakan ketentuan-ketentuan hukum perdata seperti melakukan jual beli, sewa menyewa, memborong pekerjaan, mengadakan kontrak-kontrak, dan sebagainya. ${ }^{[22]}$ Jadi hukum perdata itu juga berlaku bagi perbuatan-perbuatan pemerintah.

Untuk lebih memahami konsep dari Keputusan Tata Usaha Negara yang merupakan perbuatan hukum perdata telah diperkenalkan sebuah teori oleh indroharto yang disebut teori melebur dimana suatu keputusan tata usaha negara yang berdasarkan hukum publik dianggap melebur ke dalam suatu perbuatan hukum perdata. Instrumen hukum keperdataan yang sering digunakan oleh pemerintah adalah berupa perjanjian perdata. Setiap perjanjian yang dilakukan pemerintah tersebut selalu didahului oleh adanya suatu Keputusan Tata Usaha Negara (KTUN) yang lahir dari hukum publik yang dikeluarkan untuk melakukan suatu tindakan hukum perdata. Setelah dibuatnya keputusan TUN tersebut, maka barulah dilakukan perjanjian perdata (tindakan hukum

\footnotetext{
${ }^{21}$ Penjelasan pasal 2 huruf a UU Nomor 9 Tahun 2004. Lembaran Negara Republik Indonesia Tahun 2009 Nomor 160

${ }^{22}$ SF. Marbun dan Mahfud M.D, Pokok-Pokok Hukum, hlm. 69.
} 
perdata) yang dimaksud. ${ }^{[23]}$

Yang menjadi persoalan kemudian adalah keputusan TUN untuk melakukan suatu tindakan hukum perdata itu, apa atau bagaimana kualifikasinya ? Apakah ia merupakan keputusan TUN ataukah ia merupakan tindakan pemerintah dalam bidang hukum perdata ? kalau itu merupakan suatu KTUN maka apabila terjadi suatu sengketa dikemudian hari mengenai pelaksanaan perjanjian perdata yang telah terjadi, maka hal itu masuk dalam kompetensi absolut PTUN. Sebaliknya apabila keputusan itu dianggap melebur ke dalam tindakan hukum perdata, sehingga apabila terjadi sengketa dikemudian hari maka penyelesaiannya menjadi kompetensi absolut hakim perdata (Pengadilan Negeri). ${ }^{[24]}$ UU No. 5 tahun 1986 dengan ketentuan pasal 2 huruf a menjurus dan cenderung untuk menganggap keputusan TUN semacam itu melebur dalam tindakan hukum perdata yang menjadi tujuan akhirnya.

Dari keterangan diatas maka dapat disimpulkan bahwa yang disebut Keputusan Tata Usaha Negara yang merupakan perbuatan hukum perdata adalah suatu keputusan yang dikeluarkan oleh Badan atau Pejabat Tata Usaha Negara dalam rangka mengantarkan pemerintah untuk melakukan suatu tindakan hukum perdata sehingga kemudian hal ini menjadi pembatasan kewenangan absolut Pengadilan Tata Usaha Negara untuk memeriksa sengketa yang lahir dari KTUN yang merupakan perbuatan hukum perdata tersebut sebagaimana yang dimuat dalam Pasal 2 huruf a Undang-undang Nomor 5 Tahun 1986 tentang Peradilan Tata Usaha Negara.

\section{B. Problematika KTUN yang merupakan perbuatan hukum perdata di Pengadilan Tata Usaha Negara}

Salah satu kesulitan yang sering terjadi dengan adanya klausa Keputusan Tata Usaha Negara yang merupakan perbuatan hukum perdata adalah tidak jelasnya apakah suatu keputusan itu benar-benar bersifat hukum perdata. Memang ketentuan Pasal 2 huruf a UU Nomor 5 tahun 1986 tentang Peradilan Tata Usaha Negara tersebut menimbulkan orang bertanya dan tidak salah kalau dipertanyakan, mengapa perlu adanya pengecualian tersebut. Bukankah sudah jelas, bahwa keputusan TUN menurut hukum perdata tentu tidak mungkin sama dengan keputusan TUN yang merupakan keputusan dalam suasana hukum publik. Ternyata masalahnya tidaklah sedangkal pertanyaan tersebut. ${ }^{[25]}$

Sebagai konsekuensi yang negatif dari rumusan yang tidak jelas mengenai hakekat Keputusan Tata Usaha Negara yang merupakan perbuatan hukum perdata dalam praktek melahirkan tumpang tindih kompetensi absolut Peradilan Tata Usaha Negara dengan Peradilan yang lainnya, khususnya peradilan umum. Hal ini ditandai dengan banyaknya gugatan-gugatan yang lahir sebagai akibat dikeluarkannya Keputusan Tata Usaha Negara yang merupakan perbuatan hukum perdata tersebut.

Berikut contoh putusan PTUN yang memeriksa dan mengadili Keputusan Tata Usaha Negara yang merupakan Perbuatan Hukum Perdata antara PT Bajatra sebagai penggugat melawan PT Kereta Api Indonesia sebagi tergugat, diantaranya : Putusan PTUN Bandung Nomor 74/G/2014/ PTUN.BDG, Putusan PT TUN Jakarta Nomor 88/B/2015/PT.TUN.JKT, Putusan Mahkamah Agung Nomor 582/K/TUN/2015, Putusan Mahkamah Agung Nomor 181/PK/TUN/2016. Objek gugatan berupa Surat Keputusan Executive Vice President Logistik PT. Kereta Api Indonesia (Persero), yakni

\footnotetext{
${ }^{23}$ Indroharto, Usaha Memahami Undang-Undang, hlm. 117.

${ }^{24}$ Ibid.

${ }^{25}$ Ibid., hlm. 130.
} 
Pengadilan Tata Usaha Negara Bandung mengabulkan ${ }^{[26]}$ tuntutan penggugat dan membatalkan Surat Keputusan Executive Vice President Logistik PT. Kereta Api Indonesia (Persero), yakni Surat nomor : PL.105/V/6/KA - 2014, tanggal 30 Mei 2014 perihal Blacklist PT. Bajatra selaku Rekanan PT. Kereta Api Indonesia (Persero). Putusan ini kemudian dikuatkan dalam Putusan Majelis Hakim tingkat banding dan kasasi. Namun ketika tergugat dalam hal ini PT. KAI melakukan upaya hukum Peninjauan Kembalimakakemudian Majelis Hakim dalam Putusannya Nomor181/PK/TUN/2016 [27] malah menganulir semua putusan terdahulu dengan pertimbangan bahwa objek gugatan bukan merupakan Keputusan Tata Usaha Negara yang menjadi kompetensi absolut PTUN untuk memeriksa dan mengadilinya melainkan Keputusan Tata Usaha Negara yang merupak perbuatan hukum perdata sebagaimana maksud pasal 2 huruf a UU PTUN.

Tergugat telah menerbitkan Surat Nomor : PL.105/V/6/KA - 2014, tanggal 30 Mei 2014 perihal Blacklist PT. Bajatra selaku Rekanan PT. Kereta Api Indonesia (Persero) setelah selang waktu berjalan lebih dari 2 (dua) tahun terhitung sejak pengumuman pemenang lelang pada tanggal 9 Pebruari 2012, yang membawa akibat bagi direksi, PT. Bajatra termasuk pengurus yakni tidak diperkenankan mengikuti pengadaan barang/ jasa dilingkungan PT. Kereta Api Indonesia (Persero) untuk selamanya baik secara langsung maupun sebagai pendukung sehingga PT Bajatra merasa dirugikan baik secara materil maupun immaterial.

Dasar pertimbangan tergugat mengeluarkan keputusan yang menjadi objek sengketa adalah adanya indikasi kecurangan yang dilakukan oleh PT Bajatra diantaranya :

1) Pernyataan dalam Pakta Integritas tidak sesuai dengan kenyataan (KKN);

2) Melakukan kerjasama dengan PT.Giwin Inti untuk mengatur pengadaan sehingga terjadi persaingan yang tidak sehat (mempunyai hubungan Istimewa);

3) Saudara Abdul Kodir selaku Pemegang Saham dan Direktur I PT. Bajatra yang beralamat Jln. Brig Jend Katamso Gang Tangsi No. 49 Medan sama persis dengan alamat Sdr Kiandy Selaku Pemegang Saham dan Komisaris PT. Giwin Inti dan Saudara Henry PT. Madaco Wijaya ;

4) Adanya sanksi denda kepada perusahaan saudara untuk pekerjaan stasiun tiga gajah baru yang sampai saat ini tidak diselesaikan

Apabila di amati dari isi Putusan-Putusan sengketa antara PT Bajatra melawan PT KAI tersebut, maka bisa ditarik sebuah kesimpulan bahwa semenjak di tetapkannya pemenang lelang pengadaan Sinyal Telekomunikasi dari Stasiun Araskabu dimana bukan PT Bajatra sebagai pemenangnya maka sejak itu tidak ada lagi hubungan keperdataan yang mengikat antara PT Bajatra dan PT KAI.

26 PTUN Bandung, Putusan Nomor 74/G/2014/PTUN.BDG mengabulkan : 1. Mengabulkan gugatan Penggugat seluruhnya ; 2. Menyatakan batal Surat Keputusan Executive Vice President Logistik PT. Kereta Api Indonesia (PERSERO) Nomor : PL.105/V/6/KA-2014 tanggal 30 Mei 2014, Perihal : Blacklist PT. Bajatra selaku Rekanan PT. Kereta Api Indonesia (Persero); 3. Mewajibkan kepada Tergugat untuk mencabut Surat Keputusan Executive Vice President Logistik PT. Kereta Api Indonesia (PERSERO) Nomor : PL.105/V/6/KA-2014 tanggal 30 Mei 2014, Perihal : Blacklist PT. Bajatra selaku Rekanan PT. Kereta Api Indonesia (Persero); 4. Menghukum Tergugat untuk membayar biaya perkara sebesar Rp 219.000,- (Dua ratus sembilan belas ribu rupiah)

${ }_{27}$ Mahkamah Agung, Putusan Nomor 181/PK/TUN/2016 mengadili : mengabulkan permohonan Peninjauan Kembali dari Pemohon Peninjauan Kembali Executive Vice President Logistik PT Kereta Api Indonesia (PERSERO) ; membatalkan Putusan Mahkamah Agung Nomor 528 K/TUN/2015 tanggal 19 November 2015 ; menolak gugatan penggugat seluruhnya; menghukum Termohon Peninjauan Kembali untuk membayar biaya perkara pada semua tingkat pengadilan, yang dalam Peninjauan Kembali ditetapkan sebesar Rp2.500.000,00 (dua juta lima ratus ribu rupiah). 
Sehingga Surat Keputusan Executive Vice President Logistik PT. Kereta Api Indonesia (Persero), yakni Surat nomor : PL.105/V/6/KA - 2014, tanggal 30 Mei 2014 perihal Blacklist PT. Bajatra selaku Rekanan PT. Kereta Api Indonesia (Persero) yang dikeluarkan 2 (dua) tahun lamanya setelah ditetapkan pemenang lelang bisa dianggap sebagai sebuah Keputusan Tata Usaha Negara yang menjadi kompetensi absolut PTUN dalam memeriksa dan mengadili bukan berbentuk Keputusan Tata Usaha Negara yang merupakan perbuatan hukum perdata yang dianggap melebur.

Majelis Hakim berpendapat meskipun status dari PT. Kereta Api tersebut sebagai badan hukum perdata, namun yang penting dilihat dari segi fungsi dan kemanfaatannya merupakan urusan pemerintahan dalam rangka menyelenggarakan kemanfaatan umum. Sebagai urusan pemeritahan berarti merupakan tindakan hukum tata usaha Negara, dengan demikian masuk dalam wewenang hukum publik, karena itu objek sengketa merupakan Keputusan Tata Usaha Negara. Hakim dalam pertimbangan lainnya menganggap Keputusan Vice Presiden Logistik PT KAI bertentangan dengan Peraturan perundang-undangan, asas-asas umum pemerintahan yang baik (asas kecermatan) atas dasar melanggar kehendak umum.

Apabila hakim berpendapat bahwa Keputusan yang menjadi objek sengketa merupakan atau berdasarkan wewenang hukum publik dalam melaksanakan tugas pemerintahan, maka seharusnya yang dipersoalkan dari segi keabsahannya. Untuk itu hakim menilai dengan ukuran peraturan perundang-undangan hukum publik. Kalau penilaian dalam kasus ini berdasarkan perjanjian, ini masuk dalam ranah hukum perdata, maka yang dipersoalkan bukan lagi segi keabsahan Keputusan Vice Presiden Logistik PT KAI tetapi dari segi wanprestasi/ingkar janji, dengan demikian substansinya menjadi kewenangan dari Peradilan Umum bukan Peradilan TUN.

Berdasarkan analisis dari hasil penelitian atas kasus-kasus di atas menunjukkan adanya over lapping atau tumpang tindih kewenangan mengadili terhadap Tindak Pemerintahan berupa Keputusan Tata Usaha Negara yang melebur ke dalam perbuatan hukum perdata antara Peradilan Tata Usaha Negara dengan Peradilan Umum. Sengketa tata usaha negara yang seharusnya masuk dalam kompetensi Peradilan Tata Usaha Negara, namun kenyataan ditangani oleh Peradilan Umum. Ini berarti masih ada pembatasan terhadap kompetensi dari Peraadilan Tata Usaha Negara.

Dari contoh kasus yang dikemukakan, juga jelas terlihat, bagaimana hakim-hakim perdata mempertimbangkan, serta memutus sengketa-sengketa administrasi tersebut. Mereka pada umumnya hanya mempertimbangkan dari segi ketentuan-ketentuan perundang-undangan formal (tertulis), sangat jarang sekali mempertimbangkannya dari segi prinsip-prinsip pemerintahan itu sendiri. Penerapan AAUPB, untuk menguji suatu KTUN yang di sidangkannya, hampir tidak digunakan. ${ }^{[28]}$

Hal ini bisa dimengerti, karena mereka sudah terfokus pada tugas-tugas pokok mereka sebagai hakim peradilan umum. Mereka sangat jarang menghadapi sengketa-sengketa administrasi, sehingga sangat sedikit kesempatan mereka untuk mendalami soal-soal pemerintahan. Barangkali inilah salah satu alasan dari Perancis, mengapa mereka harus memisahkan sengketa-sengketa administrasi dari peradilan umum. ${ }^{[29]}$

\section{Konsep PTUN Dimasa Depan}

\footnotetext{
${ }^{28}$ Ibid., hlm. 261-262.

29 Ibid.
} 
Pembentukan Peradilan Administrasi Negara di Indonesia sebagai pelengkap dan kewajiban dari adanya suatu sistem negara hukum. Kewenangan yang luas yang diberikan kepada pemerintah dalam rangka menjalankan fungsi-fungsinya perlu diawasi dengan suatu sistem melalui control peradilan agar tindakannya tidak sewenang-wenang serta cacat yuridis sehingga menimbulkan kerugian bagi masyarakat. Namun setelah kurang lebih 27 (dua puluh tujuh) tahun sejak terbentuknya Peradilan Tata Usaha Negara di Indonesia, masih banyak kekurangan-kekurangan yang perlu diperbaiki secara bersama-sama oleh pihak yang terkait. Termasuk diantaranya masih sempitnya kompetensi atau kewenangan mengadili Peradilan Tata Usaha Negara.

Belajar dari Perancis dimana kewenangan yang diberikan kepada Peradilan Administrasinya sangat luas sekali termasuk sengketa mengadili tindakan pemerintah menurut hukum perdata. Kedepan masyarakat yang menghadapi masalah hukum dengan suatu Keputusan Tata Usaha Negara dan menimbulkan kerugian materil tidak perlu lagi kemudian membawa perkaranya ke Peradilan Umum untuk menuntut ganti rugi. Hal ini demi mewujudkan sistem peradilan yang cepat, sederhana dan biaya ringan di Indonesia.

Dari hasil analisis diatas, maka sebagai masukan agar terwujud suatu Peradilan Tata Usaha Negara di Indonesia yang lebih baik maka sudah saatnya diwujudkan suatu konsep PTUN yang mempunyai wewenang lebih luas dalam menangani sengketa tata usaha negara termasuk KTUN yang melebur dalam perbuatan hukum perdata. Hal ini bisa dilakukan dengan revisi terhadap Undang-Undang Nomor 5 tahun 1986 tentang PTUN.

\section{KESIMPULAN}

Dari pembahasan beberapa bab terdahulu, maka dapat ditarik kesimpulan berupa :

a. Konsep dari Keputusan Tata Usaha Negara yang merupakan perbuatan hukum perdata sebagaimana yang terdapat dalam Pasal 2 huruf a Undang-Undang Nomor 5 Tahun 1986 tentang Peradilan Tata Usaha Negara sebagai pembatasan kompetensi Peradilan Tata Usaha Negara ditentukan berdasarkan Teori Melebur. Meskipun Keputusan Tata Usaha Negara yang merupakan perbuatan hukum perdata di keluarkan oleh Badan atau Pejabat Tata Usaha Negara dalam wewenangnya berdasarkan hukum publik namun dianggap melebur ke dalam suatu perbuatan pemerintah berdasarkan hukum perdata.

b. Sebagai konsekuensi dari sulitnya membedakan antara Keputusan Tata Usaha Negara yang berdasarkan ketentuan hukum publik dengan Keputusan Tata Usaha Negara yang merupakan perbuatan hukum perdata menimbulkan terjadinya tumpang tindih kewenangan badan Peradilan Tata Usaha Negara dengan badan peradilan lainnya terutama Peradilan Umum.

\section{DAFTAR PUSTAKA}

\section{A. Buku}

Bakti, Teguh satya, dkk, Bunga Rampai Peradilan Administrasi Kontemporer, Yogyakarta : Genta Press, 2014.

Cahyawati Dwi Putri, Hukum Acara Peradilan Tata Usaha Negara, Jakarta : Gramata Publishing, 2012.

Fachruddin, Irfan, Pengawasan Peradilan Administrasi Terhadap Tindakan Pemerintah, Bandung : PT. 
Mutia Jawaz Muslim, | Tinjauan Yuridis Terhadap Keputusan Tata Usaha Negara Yang Merupakan

Alumni, 2004.

Indroharto, Usaha Memahami Undang - Undang Tentang Peradilan Tata Usaha Negara, Jakarta : Pustaka Sinar Harapan, 2002.

Lotulung, Paulus Effendie, Peradilan Tata Usaha Negara di Indonesia dibandingkan dengan Peradilan Administrasi yang Berlaku di berbagai negara, Jakarta :LPP HAN, 2003.

, Hukum Tata Usaha Negara dan Kekuasaan, Jakarta : Salemba Humanika, 2013.

Nasir Muhammad, Hukum Acara Peradilan Tata Usaha Negara, Jakarta :Djambatan, 2003.

Nugraha, Safri, dkk, Hukum Administrasi Negara, Depok : Fakultas Hukum Universitas Indonesia, 2007.

Mahmud, Pieter, Pengantar Penelitian Hukum Normatif, Jakarta: Rajawali Press: 2006.

Marbun dan Mahfud MD, Pokok - pokok Hukum Administrasi Negara, Yogyakarta : LIBERTY, 2006.

Mertokusumo Sudikno, Hukum Acara Perdata Indonesia, Yogyakarta : Liberty, 1988.

Soekanto, Soerjono, Pengantar Penelitian Hukum, Jakarta: Universitas Indonesia Press 2008.

Siahaan, Lintong o., Prospek PTUN Sebagai Pranata Penyelesaian Sengketa Administrasi Indonesia, Jakarta : Perum Percetakan Negara RI, 2005. , Berbagai Instrumen Hukum di PTUN, Jakarta : Percetakan Negara RI, 2007.

Sunindhia dan Ninik Widiyanti, Administrasi Negara dan Peradlian Administrasi, Jakarta : PT RINEKA CIPTA, 1992.

Tjakranegara, Soegijatno, Hukum Acara Peradilan Tata Usaha Negara, Jakarta : Sinar Grafika, 1994.

Usfunan Johanes, Perbuatan Pemerintah yang dapat digugat, Jakarata : Djambatan, 2002.

\section{B. Karya Ilmiah \& Internet}

Kamarullah. "Keputusan Tata Usaha Negara yang merupakan Perbuatan Hukum Perdata berdasarkan Kentuan pasal 2 butir a Undang - Undang Nomor 5 Tahun 1986 Juncto Undang-Undnag Nomor 9 Tahun 2004 tentang Perubahan atas Undang-undang Nomor 5 Tahun 1986 Tentang Peradilan Tata Usaha Negara”. Disertasi Program Pascasarjana UNAIR. Surabaya. 2008.

\section{Peraturan Perundang - undangan}

Republik Indonesia. Undang - Undang tentang Peradilan Tata Usaha Negara. UU Nomor 5 Tahun 1986. LN Tahun 1986 Nomor 77, TLN Nomor 3344.

Republik Indonesia. Peraturan Pemerintah Penerapan Undang - Undang Nomor 5 Tahun 1986 Tentang Peradilan Tata Usaha Negara. PP No. 7/1991,LN No 8/1991.

Republik Indonesia, Peraturan Pemerintah Ganti Rugi dan Tata Cara Pelaksanannya pada Tata Usaha Negara, PP No. 43 tahun 1991, LN 52/1991,TLN 3448.

Republik Indonesia, Undang - Undang Peradilan Tata Usaha Negara. UU No. 5 Tahun 1986. LN Tahun 1986 Nomor 77, TLN Nomor 3344.

Kitab Undang - Undang Hukum Perdata

\section{Putusan Pengadilan}

Pengadilan Tata Usaha Negara Semarang. Putusan Nomor 022/G/2014/PTUN.SMG.

Pengadilan Tinggi Tata Usaha Negara Surabaya. Putusan Nomor 08/B/2015/PT.TUN.SBY.

Mahkamah Agung Republik Indonesia. Putusan Nomor 382 K/TUN/2015. 
Pengadilan Tata Usaha Bandung. Putusan Nomor 74/G/2014/PTUN.BDG.

Pengadilan Tinggi Tata Usaha Negara Jakarta. Putusan Nomor 88/B/2015/PT.TUN.JKT.

Mahkamah Agung Republik Indonesia. Putusan Nomor 582/K/TUN/2015.

Mahkamah Agung Republik Indonesia. Putusan Nomor 181/PK/TUN/2016. 
Mutia Jawaz Muslim, | Tinjauan Yuridis Terhadap Keputusan Tata Usaha Negara Yang Merupakan 